\title{
GROUND RADIOMETRIC MAPPING OF ONDO STATE NIGERIA USING GAMMA RAY SPECTROMETRY AND GEOGRAPHIC INFORMATION SYSTEM
}

\author{
Gbenu S. T'., Makinde O. W'., Ajenifuja $\mathrm{E}^{\mathrm{a}^{*}}$, Olukotun S. F ${ }^{\mathrm{b}}$., Fasasi M. K ${ }^{\mathrm{a}}$, Balogun F. O. ${ }^{\mathrm{c}}$, \\ Ogundele K. T'. \\ ${ }^{a}$ Centre for Energy Research and Development, Obafemi Awolowo University, Ile-Ife, Osun, Nigeria. \\ ${ }^{b}$ Department of Physics and Engineering Physics, Obafemi Awolowo University, Ile-Ife, Osun, Nigeria. \\ 'Department of Earth Sciences, University of Oregon, Eugene, Oregon 97403, USA. \\ *Corresponding author: eajenifuja@gmail.com \\ (Received: 26th February, 2020; Accepted: 2nd November, 2020)
}

\section{ABSTRAC'T}

\begin{abstract}
The activity concentrations of ${ }^{238} \mathrm{U},{ }^{232} \mathrm{Th}$ and ${ }^{40} \mathrm{~K}$ in the soil samples of Ondo State, Nigeria, were determined using gamma spectrometry technique and the associated dose rates were calculated. The Kriging interpolation method was used to create the activity concentrations predictive maps of Ondo State with the aid of ArcGIS software. The validity of the predicted map values was established through validation and cross validation processes. The activity concentrations ranged from $19.15 \pm 0.90-83.70 \pm 3.59 \mathrm{~Bq} / \mathrm{kg}$ for ${ }^{238} \mathrm{U}, 8.01 \pm 0.39-$ $114.48 \pm 2.48 \mathrm{~Bq} / \mathrm{kg}$ for ${ }^{232} \mathrm{Th}$ and $2.75 \pm 0.13-501.98 \pm 24.56$ for ${ }^{40} \mathrm{~K}$. The absorbed dose rate was found to range from $39.39 \pm 0.21$ to $177.24 \pm 5.23 \mathrm{nGyh}^{-1}$ with an average value of $90.94 \pm 3.13 \mathrm{nGyh}^{-1}$. The predicted map obtained compares well with published values for the region. The root mean squared standardized errors obtained were $1.021194,1.024182$ and 0.998373 for ${ }^{238} \mathrm{U},{ }^{232} \mathrm{Th}$ and ${ }^{40} \mathrm{~K}$, respectively. These validated the appropriateness of the model used and the accuracy of the predicted values.
\end{abstract}

Keywords: Soil, Radioactivity; Geographic Information Systems; Map; Gamma Ray Spectrometry.

\section{INTRODUCTION}

The radionuclides, ${ }^{238} \mathrm{U},{ }^{232} \mathrm{Th}$ and ${ }^{40} \mathrm{~K}$ are naturally occurring radionuclides present in soils, building materials, rocks, oil and gas as well as food and water but their concentrations vary from one region to another (Oyebanjo and Magbagbeola, 2015; Gbenu et al., 2016a, 2016b; Kolo et al., 2016; Adedokun et al., 2019; Purnama and Damayanti, 2020; Suresh et al., 2020; Yalcin et al., 2020).The knowledge of the concentration of these radionuclides in soils and rocks is very important to radiation protection and measurements (Cross et. al., 1985; Shittu et al., 2015; Oladejo et al., 2020). Radioactivity concentration in soils is a major cause of external and internal exposure to radiation hazards. These hazards can be assessed from the determination of radioactivity concentration level in the soil (IAEA, 2004). When these radiations interact with a biological system their energy is deposited or absorbed into the cells of the system, causing ionization of some of the atoms of the cell. These can lead to a failure of the cell structure and its components, various disease condition or death (Joshi, 1991).

Ondo State in South West Nigeria is situated between $4.388^{\circ}-6.021^{\circ} \mathrm{E}$ and $5.895^{\circ}-7.737^{\circ} \mathrm{N}$. It is predominantly rocky, with many farms and settlements situated in the valleys formed by hills and mountain ranges most of which are either sedimentary or igneous in nature. Literatures show that these rock formations possess enhanced natural radioactivity (Brown and Silver, 1956; El-Arabi, 2007), a fact that have drawn many researchers to examine their associated radiation risk to humans (Ajayi and Kuforiji, 2001; Fasasi, et al., 2003; Shittu et al., 2015; Gbenu, et al., 2016; Ajayi, et al., 2018; Adagunodo et al., 2018; VincentAkpu et al., 2018; Aladeniyi et al., 2019).

The knowledge of the radioactivity concentration level of the region can be used to determine the associated population dose or the radiogenic heat contribution to the environment and in making decisions by geological agencies and urban developers. However, the comprehensive data required to make an informed decision are not available.

This work assessed the soil radioactivity concentration level of Ondo state using a systematic sampling plan, which has been widely accepted and potentially increases the accuracy of soil test and a preferred approach for sample mapping procedures (Carter, 1993; IAEA, 2003), 
in conjunction with the functionality of the Geographic Information System (GIS) to collect, process, analyze and present radiometric data in a form that is easy to interpret and visualize. We thus generate a radioactivity concentration map of Ondo state to give predicted values for the region through a validated and cross validated statistical approach. We consequently provide a state wide radioactivity concentration data, a basis on which further decisions can be made and more data can be built.

\section{METHODOLOGY}

\section{Sample Collection}

The entire Southwestern Nigeria was divided into grids of 35 sq. $\mathrm{km}$ using ArcGIS software and some google earth applications. The square grid superimposed created 11 nodes (intersections of the grid lines) in the study area, Ondo state. An average of 5 samples was collected from each node. A total of 55 soil samples were collected using the combination of the systematic grid and the systematic random sampling approaches described in IAEA (2004) in order to accommodate inaccessible locations on the sampling grid. Figure 1 shows the samples' collection points and their corresponding coordinates are recorded in Table 1 . The samples were collected at about $20 \mathrm{~cm}$ below the ground surface (IAEA, 2003). These soil samples were dried at room temperature in the laboratory to a constant mass, sieved through $2 \mathrm{~mm}$ mesh and $200 \mathrm{~g}$ of each samples was then weighed and hermetically sealed in a cylindrical polyvinylchloride (PVC) container. The samples were then kept for 28 days to attain secular equilibrium.

Once secular equilibrium was attained, gamma spectrometry measurement was carried out using the Thallium drifted Sodium Iodide ( $\mathrm{NaI}(\mathrm{Tl})$ ) detector at the Centre for Energy Research and Development (CERD), Obafemi Awolowo University, Ile-Ife, Osun State, Nigeria.

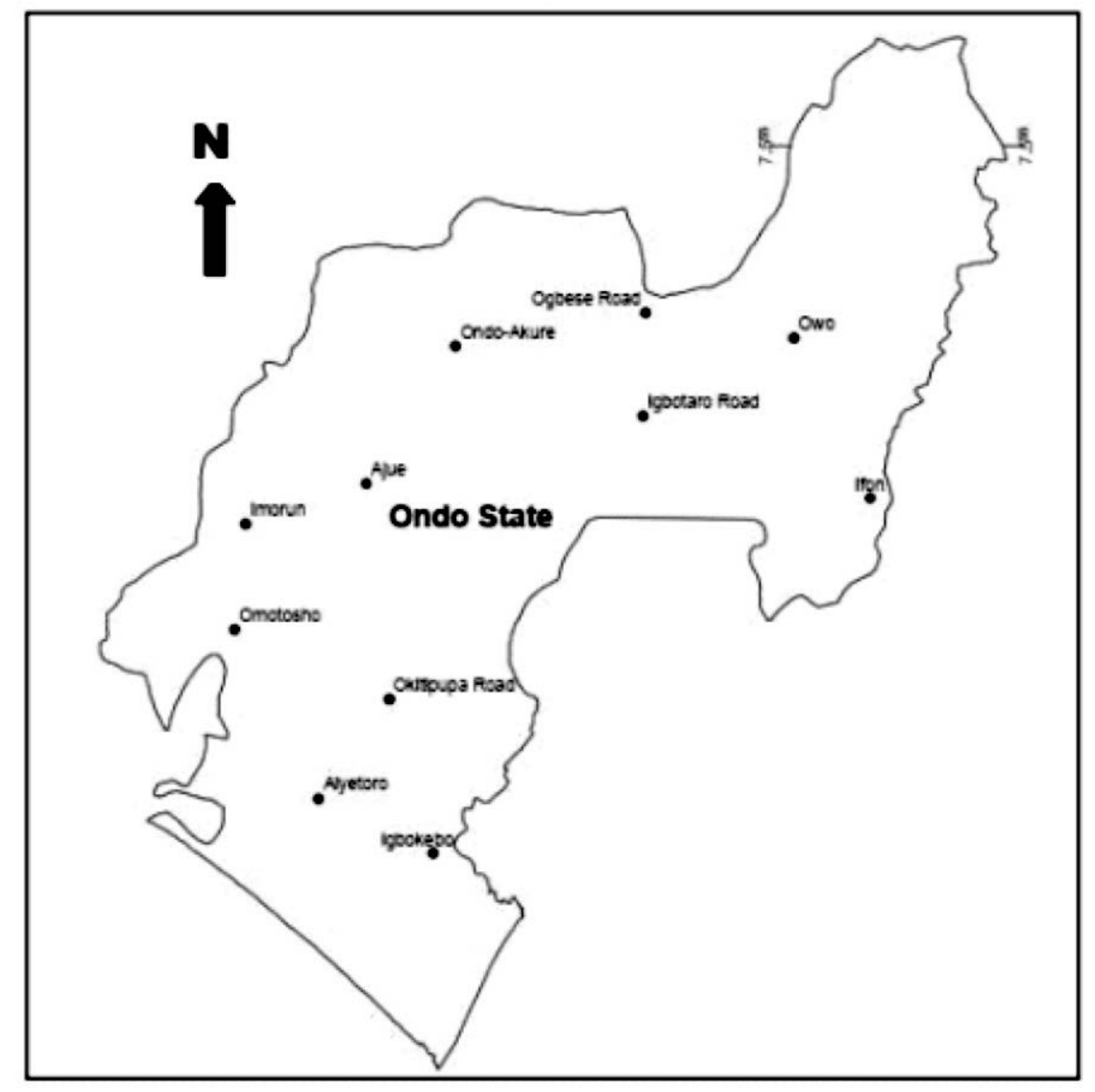

Figure 1: Samples' collection points in Ondo State 
Table 1: Location and Elevations of samples collected

\begin{tabular}{llll}
\hline \hline Location & Latitudes $\left({ }^{\circ} \mathbf{E}\right)$ & Longitudes $\left({ }^{\circ} \mathbf{N}\right)$ & Elevation $(\mathbf{m})$ \\
\hline \hline Igbotaro Road & 7.068870 & 5.352930 & 287 \\
\hline Ogbese Road & 7.255073 & 5.358400 & 316 \\
\hline Owo & 7.209950 & 5.623710 & 283 \\
\hline Ifon & 6.921565 & 5.761182 & 196 \\
\hline Ondo-Akure & 7.195662 & 5.015908 & 253 \\
\hline Aiyetoro & 6.382480 & 4.770160 & 10 \\
\hline Igbokebo & 6.285205 & 4.976057 & 13 \\
\hline Okitipupa Road & 6.561305 & 4.896392 & 28.4 \\
\hline Omotosho & 6.686678 & 4.619023 & 92.1 \\
\hline Imorun & 6.874900 & 4.638523 & 98.2 \\
\hline Ajue & 6.948165 & 4.855367 & 234 \\
\hline \hline
\end{tabular}

\section{Gamma ray spectroscopic technique}

The activity concentrations of natural radioactivity in the collected samples were determined using an adequately lead shielded $7.62 \mathrm{~cm} \times 7.62 \mathrm{~cm} \mathrm{NaI}$ (Tl) detector. Counting was carried on for 18,000 s to obtain statistically significant counts under the photo peaks of the count spectra. The gamma ray photo peaks obtained with consistency correspond to the energies $1120.3 \mathrm{keV}\left({ }^{214} \mathrm{Bi}\right), 911.21 \mathrm{keV}\left({ }^{228} \mathrm{Ac}\right)$ and $1460.82 \mathrm{keV}\left({ }^{40} \mathrm{~K}\right)$ for ${ }^{238} \mathrm{U},{ }^{232} \mathrm{Th}$ and ${ }^{40} \mathrm{~K}$, respectively. The activities of various radionuclides were determined in $\mathrm{Bq} / \mathrm{kg}$ from the count spectra. The detection limits of the $\mathrm{NaI}(\mathrm{Tl})$ detector system were calculated as $6.77,11.40$, and $12.85 \mathrm{~Bq} / \mathrm{kg}$ for ${ }^{40} \mathrm{~K}$, ${ }^{232} \mathrm{Th}$, and ${ }^{238} \mathrm{U}$, respectively following the procedure adopted by Battist et al., 2000 given as:

$M D A=\frac{3+4.65 \sqrt{B}}{t \varepsilon M}$

Where $B$ is the background counts, $t$ is the acquisition time (s) and $\varepsilon$ is the efficiency for the energy peak.

\section{Dose Rates $\left(D_{R}\right)$}

In order to convert the activity concentration to absorbed dose rate in air at $1 \mathrm{~m}$ above the ground surface, dose coefficients of $0.92 \mathrm{nGy} / \mathrm{h}$ per $\mathrm{Bq} / \mathrm{kg}$ for ${ }^{238} \mathrm{U}, 1.1 \mathrm{nGy} / \mathrm{h}$ per Bq/ $\mathrm{kg}$ for ${ }^{232} \mathrm{Th}$ and $0.080 \mathrm{nGy} / \mathrm{h}$ per $\mathrm{Bq} / \mathrm{kg}$ for ${ }^{40} \mathrm{~K}$ were used as given by ICRP, 2003 in equation 2 :

$$
D_{R}(n G y / h)=0.92 \times C_{U}+1.1 \times C_{T h}+0.08 \times C_{K}
$$

Where $\mathrm{C}_{\mathrm{U}}$ is the activity concentration of ${ }^{238} \mathrm{U}, \mathrm{C}_{\mathrm{Th}}$ is the activity concentration of ${ }^{232} \mathrm{Th}, \mathrm{C}_{\mathrm{K}}$ activity concentration of ${ }^{40} \mathrm{~K}$ in $\mathrm{Bq} / \mathrm{kg}$ and $\mathrm{D}_{\mathrm{R}}$ is the dose rate in $n G y / h$

\section{Geographic Information System Technique}

In order to create a continuous map of Ondo state, the mean gamma ray activities for each grid along with their representative coordinates were fed into ArcGIS software, to carry out the spatial interpolation - theprocess of using points (geographic coordinates) with known values to estimate values at other unknown points (Shahab, 2008).

The method of interpolation used was Kriging. Kriging has the ability to create a variogram and covariance functions required to estimate the statistical dependence values of the model of autocorrelation that fit the nature of the data under consideration. This makes it more appropriate and accurate than other interpolation methods such as Inverse Distance Weighting (IDW). The procedure begins with equation 3 (ESRI, 2012):

$\hat{\mathrm{Z}}\left(S_{o}\right)=\sum_{i=1}^{N} \lambda_{i} Z\left(S_{i}\right)$

where;

$Z\left(S_{i}\right)=$ the measured value at the $i$ th location 
$\ddot{e}_{i}=$ an unknown weight for the measured value at the $i$ th location

$\hat{Z}\left(S_{\text {o }}\right)=$ the predicted value at the prediction location.

It then creates an empirical semivariogram using the equation 3 , and fit a model to its pointsin order to determine $\ddot{e}_{i}(\mathrm{ESRI}, 2012)$ required in equation 1.

$$
\begin{aligned}
& S(\text { distance }, h)=(0.5 \times \text { Average } \\
& \left((\text { value } i-\text { value } j)^{2}\right)
\end{aligned}
$$

Where, $\mathrm{S}$ is the semivariogram distance, $i$ and $j$ are two points.

The accuracy of the interpolated values was determined through validation and crossvalidation processes along with a comparison of the predictions with the results from literature.

\section{RESULTS AND DISCUSSION}

\section{Activity Concentration and Dose Rates}

The mean specific activities of the radionuclides in the samples of each grid for ${ }^{238} \mathrm{U},{ }^{232} \mathrm{Th}$ and ${ }^{40} \mathrm{~K}$ are presented in Table 2 . The highest ${ }^{40} \mathrm{~K}$ activity concentration of $501.98 \pm 24.56 \mathrm{~Bq} / \mathrm{kg}$ was recorded at Igbotaro Road with the lowest value of $27.5 \pm 0.13 \mathrm{~Bq} / \mathrm{kg}$ at Ajue. The activity concentration of ${ }^{238} \mathrm{U}$ ranged from $19.15 \pm 0.90$ to $83.70 \pm 3.59 \mathrm{~Bq} / \mathrm{kg}$ with highest value of $83.70 \pm 3.59 \mathrm{~Bq} / \mathrm{kg}$ at Igbokebo. While the activity concentration of ${ }^{232} \mathrm{Th}$ ranged between $8.01 \pm 0.39$ and $114.48 \pm 2.48 \mathrm{~Bq} / \mathrm{kg}$. The obtained results differ from activity concentration reported by Aladeniyi et al. (2019) and Olawale et al. (2018) of radionuclides in soil collected at Owo LGA and Gbeleju-Loda, respectively. This can be attributed to differences in methods of samples collection.

The absorbed dose rate in air at $1 \mathrm{~m}$ above the ground for each grid was evaluated and given in column 5 of Table 2 . The absorbed dose rate ranged between $39.39 \pm 0.21$ and $177.24 \pm 5.23$ nGy hr ${ }^{-1}$, with highest value at Ogbese Road and lowest at Imorun. it was noticed that the dose rate increases with increasing latitude or distance from sea level (elevation). The highest sampled location was Ogbese Road at 316 metres above sea level, while Aiyetoro was the lowest location at 10 metres above the sea level. Figure 3 shows the elevation of the sampled locations against their latitude presenting the topography of Ondo State. This variation can be attributed to the predominant rock formation in the region (Alnour et al., 2012; Gbenu et al., 2015).

\begin{tabular}{|c|c|c|c|c|}
\hline Locations & ${ }^{238} \mathrm{U}(\mathrm{Bq} / \mathrm{kg})$ & ${ }^{232} \mathrm{Th}$ (Bq/kg) & ${ }^{40} \mathrm{~K}(\mathrm{~Bq} / \mathrm{kg})$ & Dose Rates (nGyhr-1) \\
\hline Igbotaro Road & $30.88 \pm 0.85$ & $26.82 \pm 1.29$ & $501.98 \pm 24.56$ & $98.06 \pm 4.17$ \\
\hline Ogbese Road & $23.83 \pm 1.15$ & $114.48 \pm 2.48$ & $367.42 \pm 17.98$ & $177.24 \pm 5.23$ \\
\hline Owo & $75.88 \pm 1.69$ & $25.04 \pm 1.20$ & $382.96 \pm 18.74$ & $128.00 \pm 4.38$ \\
\hline Ifon & $43.15 \pm 1.10$ & $16.13 \pm 0.78$ & $40.05 \pm 1.96$ & $54.23 \pm 1.71$ \\
\hline Ondo-Akure & $52.93 \pm 1.27$ & $22.15 \pm 1.07$ & $268.71 \pm 13.15$ & $94.56 \pm 3.40$ \\
\hline Aiyetoro & $31.22 \pm 0.85$ & $8.33 \pm 0.41$ & $143.44 \pm 7.02$ & $49.36 \pm 1.79$ \\
\hline Igbokebo & $83.70 \pm 3.59$ & $8.01 \pm 0.39$ & $66.98 \pm 3.43$ & $91.18 \pm 4.01$ \\
\hline Okitipupa Road & $50.55 \pm 1.23$ & $28.31 \pm 1.36$ & $56.29 \pm 3.56$ & $82.15 \pm 2.92$ \\
\hline Omotosho & $56.07 \pm 1.33$ & $47.64 \pm 2.28$ & $138.73 \pm 6.79$ & $115.09 \pm 4.28$ \\
\hline Imorun & $19.15 \pm 0.90$ & $24.99 \pm 0.68$ & $71.43 \pm 3.55$ & $39.39 \pm 0.21$ \\
\hline Ajue & $47.05 \pm 1.02$ & $25.06 \pm 1.21$ & $27.5 \pm 0.13$ & $71.07 \pm 2.278$ \\
\hline
\end{tabular}

Table 2: Measured Average Activities and Dose rates 


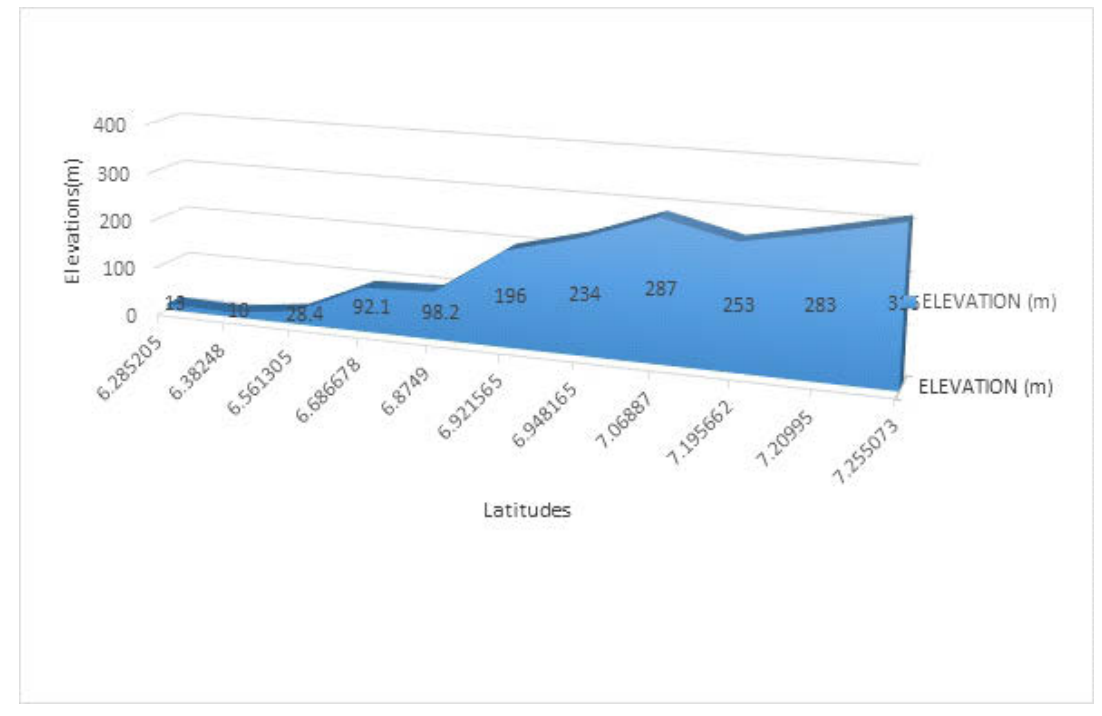

Figure 2: Topography of Sampled Locations

GIS interpolation and predicted maps of activity concentration of radionuclides in Ondo State

The maps of ${ }^{238} \mathrm{U},{ }^{232} \mathrm{Th}$ and ${ }^{40} \mathrm{~K}$ activity concentrations in Ondo State Nigeria are presented in Figures 3, 4 and 5, respectively. The activity concentration of ${ }^{40} \mathrm{~K}$ in Figure 5 increased with increasing altitude and elevation when compared with Figure 2. This indicates a strong correlation between the basement rocks and the activity concentration of ${ }^{40} \mathrm{~K}$. This region is the Pan-African Granite, Granite - Gneiss, Effon Psammite formation and Amphibolite schist, all known to exhibit enhanced naturally occurring radioactivity (Alnour, et al., 2012). The ${ }^{238} \mathrm{U}$ and ${ }^{232} \mathrm{Th}$ maps (Figure 4 and 5 ) do not have any define trend as their concentrations are determined by factors such as human activities and solubility of their ores in water. Uranium can be leached or accumulated in some horizons of the soil profile and can be transported both vertically (groundwater) and horizontally (surface) (Layton \& Armstrong, 1994).

For the assessment of uncertainty to be validated and to estimate the variability of the predictions from the true values, the root mean squared standardized errors should be close to 1 and the mean of standardized prediction errors should also be in the neighbourhood of zero (ESRI, 2012). For this work, the root mean squared standardized errors obtained were 1.021194, 1.024182 and 0.998373 for ${ }^{238} \mathrm{U},{ }^{232} \mathrm{Th}$ and ${ }^{40} \mathrm{~K}$, respectively. Meanwhile, the mean of the standardized error were $0.004884,0.003178$, and 0.001852 for ${ }^{238} \mathrm{U},{ }^{232} \mathrm{Th}$ and ${ }^{40} \mathrm{~K}$, respectively. These show that the interpolation values are accurate, the method and the model used were appropriate for this study. 


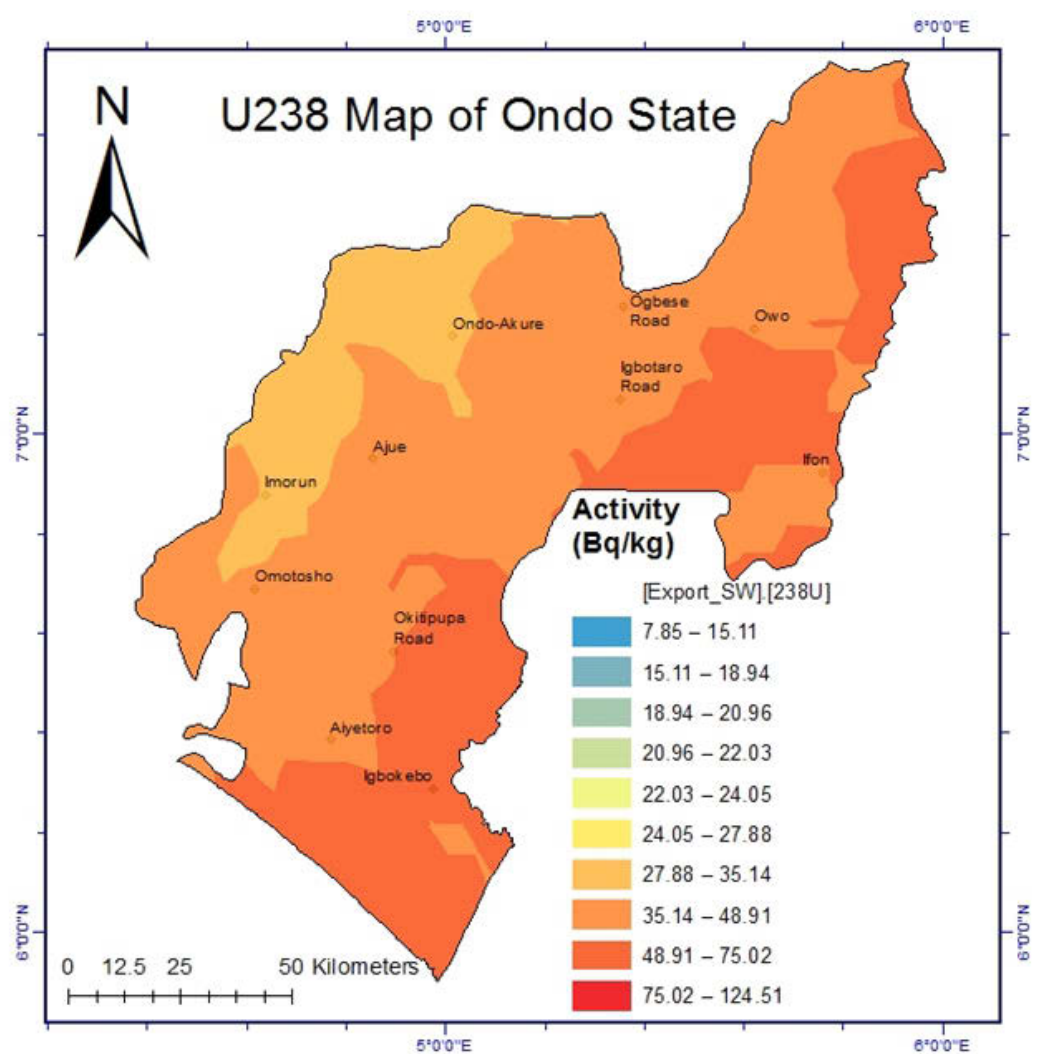

Figure 3: ${ }^{238} \mathrm{U}$ Predicted Activity Concentration Map of Ondo State

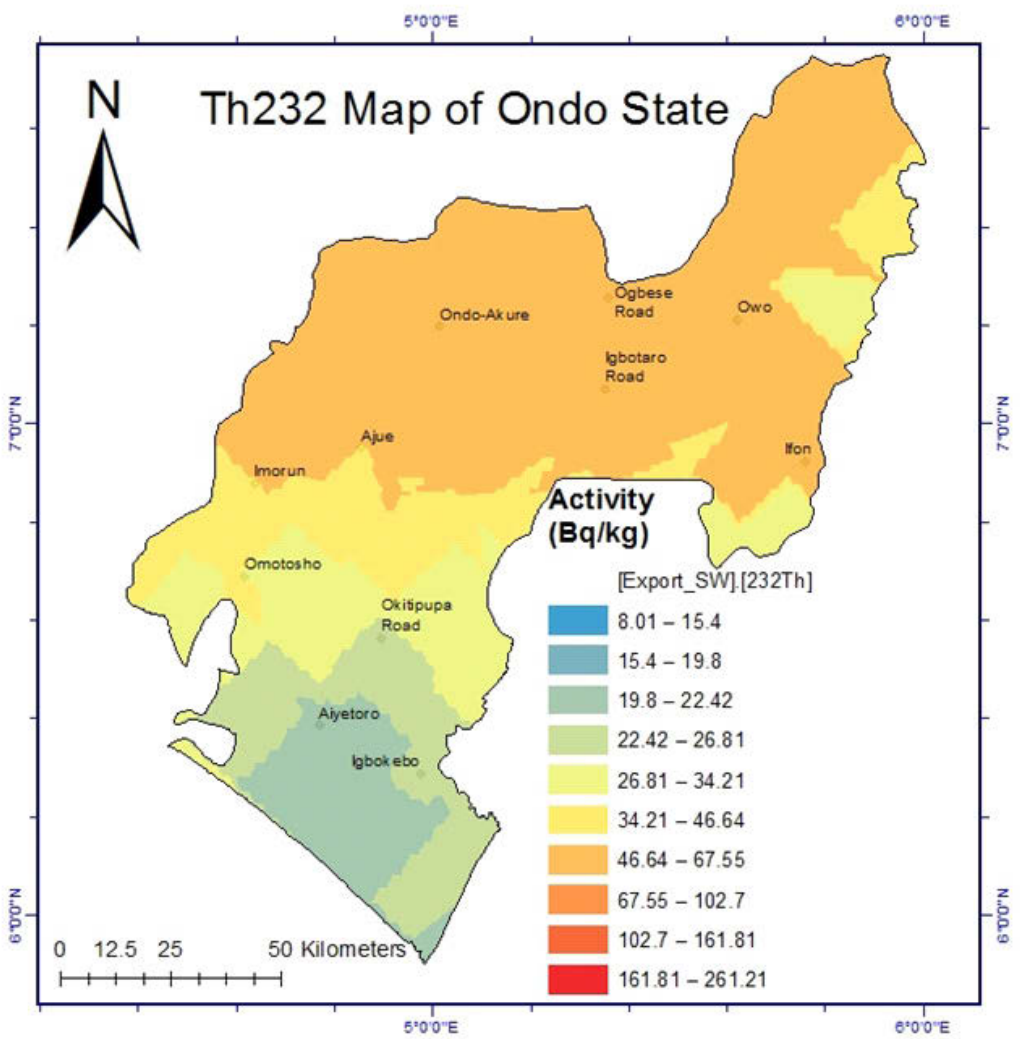

Figure 4: ${ }^{232}$ Th Predicted Activity Concentration Map of Ondo State 


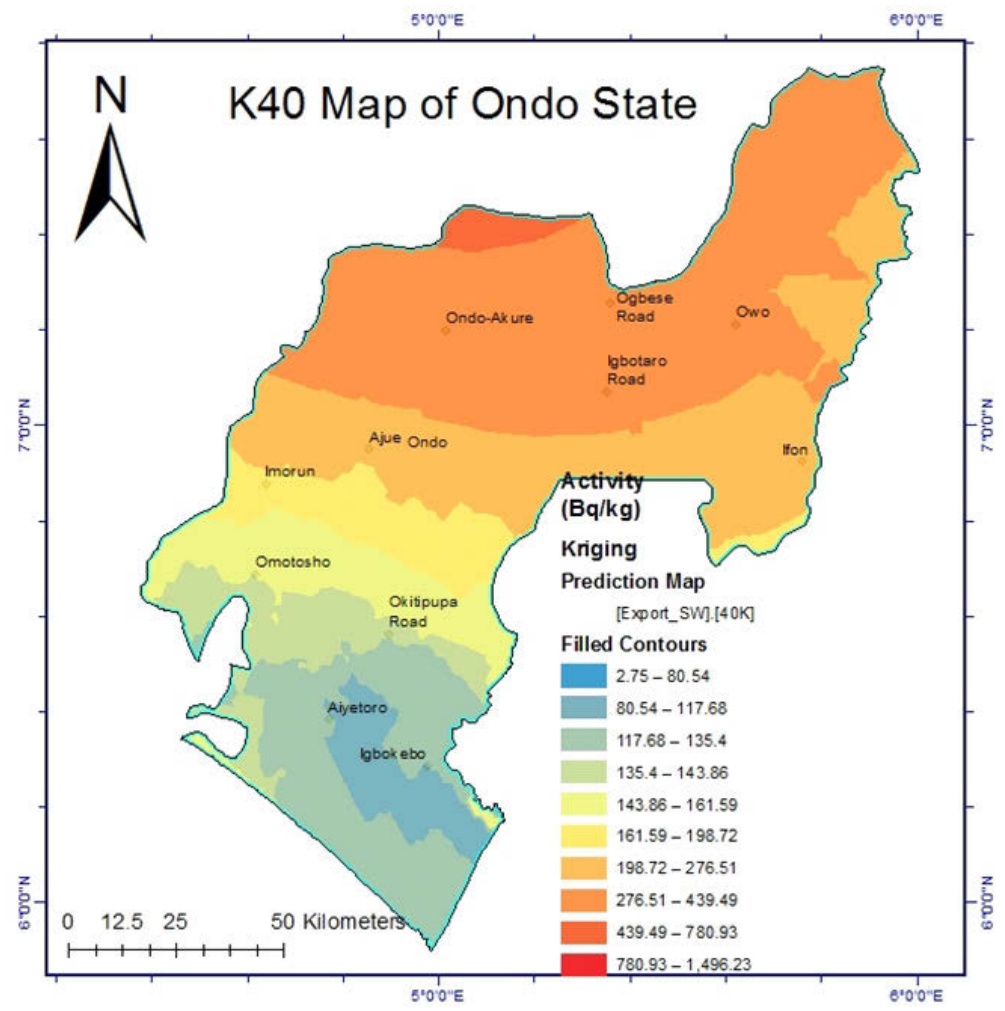

Figure $5:{ }^{40} \mathrm{~K}$ Predicted Activity Concentration Map of Ondo State

\section{CONCLUSIONS}

The activity concentrations of ${ }^{238} \mathrm{U},{ }^{232} \mathrm{Th}$ and ${ }^{40} \mathrm{~K}$ in soils of Ondo State Nigeria have been determined by gamma ray spectrometry and the predicted maps of the activity concentrations of ${ }^{238} \mathrm{U},{ }^{232} \mathrm{Th}$ and ${ }^{40} \mathrm{~K}$ have been produced with the aid of the proven statistical accuracy of Kriging method. The validity of the predicted map values was established through validation and cross validation processes. Hence, the ${ }^{238} \mathrm{U},{ }^{232} \mathrm{Th}$ and ${ }^{40} \mathrm{~K}$ activity concentration map produced are reliable and can now be used as a baseline data for radioactivity measurement against which any future measurement in Ondo State Nigeria can be compared.

\section{REFERENCES}

Adedokun, M.B., Aweda, M.A., Maleka, P.P., Obed, R.I., Ogungbemi, K.I., Ibitoye, Z.A. (2019). Natural radioactivity contents in commonly consumed leafy vegetables cultivated through surface water irrigation in Lagos state, Nigeria. J. Radiat. Res. Appl. Sci. 12, 147-156. https://doi.org/10.1080/16878507.2019
.1618084

Ajayi, O. S., Dike, C. G., \& Balogun, K. O. (2018). Elemental and radioactivity analysis of rocks and soils of some selected sites in Southwestern Nigeria. Environmental Forensics, 87-98.

Aladeniyi, K., Olowookere, C., Oladele, B.B. (2019). Measurement of natural radioactivity and radiological hazard evaluation in the soil samples collected from Owo, Ondo State, Nigeria. J. Radiat. Res. Appl. Sci. 12, 200-209. https://doi.org/10.1080/16878507.2019 .1593675

Vincent-Akpu, I. F., Babatunde, B. B., \& Ndimel, P. E. (2018). Occurrence of Radioactive Elements in Oil-Producing Region of Nigeria. Ch. 11,. In I. F. Vincent-Akpu, B. B. Babatunde, \& P. E. Ndimel, The Political Ecology of Oil and Gas Activities in the Nigerian Aquatic Ecosystem (pp. 149-158).

L a g o s : $\quad$ E l s e vi e r. doi:https://doi.org/10.1016/C2015-005649-0

Adagunodo, T. A., Aizebeokhai, A. P., \& Oyeyemi, K. D. (2018). Groundwater Exploration in 
Aaba Residential Area of Akure, Nigeria. Frontiers in Earth Science, 1-12.

Ajayi, I. R., \& Kuforiji, O. O. (2001). Natural radioactivity measurements in rock samples of Ondo and Ekiti states in Nigeria. Radiation measurements, 33(1), 1316.

Alnour, I. A., Wagiran, H., Ibrahim, N., Laili, Z., Omar, M., Hamzah, S., \& Bello, Y. I. (2012). Natural radioactivity measurements in the granite rock of quarry sites, Johor, Malaysia. Radiation Physics and Chemistry Omar M., Hamzah S., Bello.Y. Idi, 81, 1842-1847.

Brown, H., \& Silver, L. T. (1956). The Possibilities of Obtaining Long-Range Supplies of Uranium, Thorium, and Other Substances from Igneous Rocks. Califonia Institute of Technology, 91 - 95. Retrieved from authors.library.caltech.edu.

Carter, M. R. (1993). Soil sampling and methods of analysis. (C. Science., Ed.) 1993, London: Boca Raton.

Cross , F. T., Harley, N. H., \& Hofmann, W. (1985). Measurement of radon concentration in ground water. Health Physics, 48, 649.

El-Arabi, A. M. (2007). 226Ra, 232Th and 40K concentrations in igneous rocks from eastern desert, Egypt and its radiological implications. Radiation Measurements, 42(1), 94-100.

ESRI. (2012, March). ArcGIS Resources. Retrieved 2016, from ArcGIS Help 10.1: http://resources.arcgis.com/en/help/mai $\mathrm{n} / 10.1 /$ index.html

Fasasi, M. K., Oyawale, A. A., Mokobia, C. E., Tchokossa, P., Ajayi, T. R., \& Balogun, F. A. (2003). Natural radioactivity of the tarsand deposits of Ondo State, Southwestern Nigeria. Nuclear Instruments and Methods in Physics Research Section A: Accelerators, Spectrometers, Detectors and Associated Equipment, 505(1-2), 449-453.

Gbenu, S. T., Oladejo, O. F., Alayande, S. O., Olukotun, S. F., Fasasi, M. K., \& Balogun, F. A. (2016). Assesment of Radiological Hazards of Quarry Products in Southwest Nigeria. Journal of Radiation Research and Applied Sciences, 9(1), 20 - 25. Retrieved from https://doi.org/10.1016/ j.jrras.2015.08.004
IAEA. (2003). Guidelines for radioelement mapping using gamma ray spectrometry data. IAEA TECDOC_1363. Vienna: IAEA.

IAEA. (2004). Soil Sampling for Environmental Contaminants. IAEA-TECDOC-1415. Vienna: International Atomic Energy Agency (IAEA).

Issa, S.A.M., Uosif, M.A.M., Tammam, M., Elsaman, R. (2014). A comparative study of the radiological hazard in sediments samples from drinking water purification plants supplied from different sources. J. Radiat. Res. Appl. Sci. 7, 80-94. https://doi.org/10.1016/j.jrras.2013.12. 006.

Joshi, S. R. (1991). Radioactivity in Great Lake. Science of the Total Environment, 100, 61-104.

Layton, D. W., \& Armstrong, A. Q. (1994). Methodological considerations for determining cleanup limits for uranium in treated and untreated soils. Journal of Soil Contamination, 3(4), 319-348.

Kolo, M.T., Khandaker, M.U., Amin, Y.M., Abdullah, W.H.B. (2016). Quantification and Radiological Risk Estimation Due to the Presence of Natural Radionuclides in Maiganga Coal, Nigeria. PLoS One 11. https://doi.org/org/10.1371/journal.po ne. 0158100

Oladejo, O.F., Olukotun, S.F., Ogundele, L.T., Gbenu, S.T., Fakunle, M.A. (2020). Radiological risk assessment of naturally occurring radioactive materials (NORMS) from selected quarry sites in Edo State, South-south, Nigeria. Environ. Earth Sci. 79, 1-8. https://doi.org/10. 1007/s12665-020-8842-7

Oyebanjo, O. A and Magbagbeola, A. G. (2015). Radionuclide analysis of drinking water in selected secondary schools of Epe local government area, Lagos state, Nigeria. Nigeria Journal of Pure \& Applied Physics, 6, (1), $40-45$.

P. Battist, C. M. Castellani, H. Doerfel, G. Tarroni (2000). Problems in Defining the Minimum Detectable Activity in Lungs Measurement of Low Energy Photon Emitters. Radiation Protection Dosimetry, 89, $251-254$.

Purnama, D.S., Damayanti, T. (2020). 
Determination of internal and external hazard index of natural radioactivity in well water samples. J. Phys. Conf. Ser. 1436, 12090. https://doi.org/10. 1088/1742-6596/1436/1/012090

Shahab , F. (2008). GIS Basics. New Delhi - 11000: New Age International (P) Limited.

Shittu, H.O., Olarinoye, I.O., Baba-Kutigi, A.N., Olukotun, S.F., Ojo, E.O., Egga, A. (2015). Determination of the Radiological Risk Associated with Naturally Occurring Radioactive Materials (NORM) at Selected Quarry Sites in Abuja FCT, Nigeria: Using Gamma-Ray Spectroscopy, Physics Journal, 1(2), 71- 78.

Suresh, S., Rangaswamy, D.R., Srinivasa, E.,
Sannappa, J. (2020). Measurement of radon concentration in drinking water and natural radioactivity in soil and their radiological hazards. J. Radiat. Res. Appl. Sci. $13, \quad 12-26$. https://doi.org/10.1080/16878507.2019 .1693175

Yalcin, F., Ilbeyli, N., Demirbilek, M., Yalcin, M.G., Gunes, A., Kaygusuz, A., Ozmen, S.F. (2020). Estimation of Natural Radionuclides' Concentration of the Plutonic Rocks in the Sakarya Zone, Turkey Using Multivariate Statistical Methods. Symmetry (Basel). 12, 1048. https://doi.org/10.3390/sym12061048 